\title{
Oxidative Nanopatterning of Titanium Surface Influences mRNA and MicroRNA Expression in Human Alveolar Bone Osteoblastic Cells
}

\author{
Maidy Rehder Wimmers Ferreira, ${ }^{1}$ Roger Rodrigo Fernandes, ${ }^{1}$ \\ Amanda Freire Assis, ${ }^{2}$ Janaína A. Dernowsek, ${ }^{2}$ Geraldo A. Passos, ${ }^{1,2}$ \\ Fabio Variola, ${ }^{3}$ and Karina Fittipaldi Bombonato-Prado ${ }^{1}$ \\ ${ }^{1}$ Cell Culture Laboratory, Department of Morphology, Physiology and Basic Pathology, School of Dentistry of Ribeirão Preto, \\ University of São Paulo, 14040-904 Ribeirão Preto, SP, Brazil \\ ${ }^{2}$ Molecular Immunogenetics Group, Department of Genetics, Ribeirão Preto Medical School, \\ University of São Paulo, 14049-900 Ribeirão Preto, SP, Brazil \\ ${ }^{3}$ Faculty of Engineering, Department of Mechanical Engineering, University of Ottawa, Ottawa, ON, Canada K1N 6N5
}

Correspondence should be addressed to Karina Fittipaldi Bombonato-Prado; karina@forp.usp.br

Received 26 November 2015; Revised 30 March 2016; Accepted 5 April 2016

Academic Editor: Esmaiel Jabbari

Copyright ( 2016 Maidy Rehder Wimmers Ferreira et al. This is an open access article distributed under the Creative Commons Attribution License, which permits unrestricted use, distribution, and reproduction in any medium, provided the original work is properly cited.

\begin{abstract}
Titanium implants have been extensively used in orthopedic and dental applications. It is well known that micro- and nanoscale surface features of biomaterials affect cellular events that control implant-host tissue interactions. To improve our understanding of how multiscale surface features affect cell behavior, we used microarrays to evaluate the transcriptional profile of osteoblastic cells from human alveolar bone cultured on engineered titanium surfaces, exhibiting the following topographies: nanotexture $(\mathrm{N})$, nano+submicrotexture (NS), and rough microtexture (MR), obtained by modulating experimental parameters (temperature and solution composition) of a simple yet efficient chemical treatment with a $\mathrm{H}_{2} \mathrm{SO}_{4} / \mathrm{H}_{2} \mathrm{O}_{2}$ solution. Biochemical assays showed that cell culture proliferation augmented after 10 days, and cell viability increased gradually over 14 days. Among the treated surfaces, we observed an increase of alkaline phosphatase activity as a function of the surface texture, with higher activity shown by cells adhering onto nanotextured surfaces. Nevertheless, the rough microtexture group showed higher amounts of calcium than nanotextured group. Microarray data showed differential expression of 716 mRNAs and 32 microRNAs with functions associated with osteogenesis. Results suggest that oxidative nanopatterning of titanium surfaces induces changes in the metabolism of osteoblastic cells and contribute to the explanation of the mechanisms that control cell responses to micro- and nanoengineered surfaces.
\end{abstract}

\section{Introduction}

Over the last three decades, orthopedics and oral and maxillofacial surgery have used titanium as the metallic material of choice because of its excellent biocompatibility, mainly associated with (1) elastic modulus similar to that of bone, (2) excellent corrosion resistance due to a superficial $\mathrm{TiO}_{2}$ layer, and (3) biological inertness in vivo [1]. These advantages have boosted the application of titanium, ranging from femoral stems to prosthetic devices to replace dental elements [2].
However, specific physiological aspects such as implantation site, blood supply, and quality and quantity of the surrounding bone tissue can interfere with the osseointegration process, ultimately determining the success rate of an implant [3]. In addition to these factors, the metal physicochemical properties (e.g., topography, roughness, chemical composition, and wettability) at various scales will also contribute to the determination of the outcome of the osseointegration process by affecting the cellular and extracellular events that occur during implant-host tissue interactions [4]. 
The abilities to promote the interactions with adjacent tissues and to elicit the biological response by guiding specific cellular processes along predetermined routes are fundamental characteristics that the next generation of biomaterials should possess [5]. It is now widely accepted that the rational design of surface topography at the micro- and nanoscale is a powerful tool to control and guide cellular response [6]. The topography of a surface can in fact influence cellular response from surrounding tissues by modifying cell adhesion and migration, proliferation, and collagen synthesis at the material-host tissue interface [7]. Similarly, surface chemistry is another key parameter that plays a fundamental role in peri-implant bone apposition [8].

Numerous techniques have been developed to engineer titanium surfaces in ways to promote bone cell growth and ultimately implant fixation. Several studies have shown how different types of titanium surface treatment affect these processes and highlighted how micro- and nanopatterned surfaces exert a differential influence on bone formation and cell behavior obtained from tissues adjacent to the implant surfaces [7]. In this context, cell cultures are a useful tool, because they allow investigation into how cells and matrices interact with the titanium surface [9]. Currently, the investigation of gene expression patterns is increasingly gaining interest, aiming at unveiling the functional roles of genes and enabling new approaches in cell therapies [10]. Tools such as microarrays can now be used to identify gene modulation in cells that are in contact with biomaterials, as reported by Bombonato-Prado et al. [11]. Microarrays can ultimately help to identify differentially regulated genes in osteoblasts exposed to different biomaterials used in bone regeneration/substitution procedures.

The present study relied on biochemical assays and gene expression to evaluate differences in the cellular response of human alveolar bone cells cultured on different titanium surfaces. Our results showed that nanoporous titanium surfaces generated by oxidative nanopatterning influence alveolar bone cells behavior and, distinctively from previous studies, there were investigated differences in the expression of mRNAs and microRNAs of such cells in contact with the distinct topographies.

\section{Materials and Methods}

2.1. Titanium Surfaces Preparation. Commercially pure grade 2 titanium (Ti) discs, with diameter of $13 \mathrm{~mm}$ and thickness of $2 \mathrm{~mm}$, were polished with an Exakt $400 \mathrm{CS}$ machine equipped with 320, 500, 800, 2500, and 4000 grits (Exakt Advanced Technologies, Germany) and successively polished with felt and abrasive particles of alumina paste $\left(\mathrm{Al}_{2} \mathrm{O}_{3}\right)(0.05 \mathrm{mM})$. The titanium discs were sonicated in Extran ${ }^{\circledR}$ MA 02 (Merck Millipore, USA) 2\% diluted in deionized water, followed by alcohol $70 \%$ and deionized water for 30 minutes each. Next, simple yet efficient chemical etching based on a mixture of sulfuric acid $\left(\mathrm{H}_{2} \mathrm{SO}_{4}\right.$ at $\left.36 \mathrm{~N}\right)$ and hydrogen peroxide $\left(\mathrm{H}_{2} \mathrm{O}_{2(\mathrm{aq})}\right)$ was applied at varying relative concentrations of the acid and the peroxide, at different temperatures. This procedure afforded three different types of titanium surface, as described in a previous article [5]. Application of a fully programmable digital hot plate (EchoTherm ${ }^{\mathrm{TM}} \mathrm{HS} 40$, Torrey Pines Scientific, USA) with automatic feedback ensured temperature control. To obtain the nanotextured surface $(\mathrm{N})$, the titanium discs were submitted to etching with 50:50 $\mathrm{H}_{2} \mathrm{SO}_{4}(36 \mathrm{~N}) / 30 \%$ aqueous hydrogen peroxide $\left(\mathrm{H}_{2} \mathrm{O}_{2(\mathrm{aq})}\right)$ at $25^{\circ} \mathrm{C}$. To achieve the nano+submicrotextured surface (NS), the titanium discs were treated with 50:50 $\mathrm{H}_{2} \mathrm{SO}_{4}$ $(36 \mathrm{~N}) / 30 \%$ aqueous hydrogen peroxide $\left(\mathrm{H}_{2} \mathrm{O}_{2(\mathrm{aq})}\right)$ at $50^{\circ} \mathrm{C}$. Treatment of the titanium discs with $30 \%$ aqueous hydrogen peroxide $\left(\mathrm{H}_{2} \mathrm{O}_{2(\mathrm{aq})}\right)$ solution alone at $50^{\circ} \mathrm{C}$ was used to obtain the rough microtextured (MR) surface. Untreated polished titanium discs served as control (C). Before experiments, treated and untreated (control) titanium discs were rinsed with deionized $\mathrm{H}_{2} \mathrm{O}$, autoclaved, and air-dried. To confirm the presence of different surface topographies, the titanium discs were examined under a field emission scanning electron microscope (Zeiss LEO 440, Cambridge, England) operated at $15 \mathrm{kV}$.

2.2. Cell Culture. Human alveolar bone fragments were obtained from healthy adult donors with their informed consent, using the research protocols approved by the Committee of Ethics in Research of the School of Dentistry of the University of São Paulo (approval number 2011.1.1015.58.6). The osteoblastic cells were kept in culture flasks until subconfluence and then seeded over titanium discs in 24well culture plates at a concentration of $2 \times 10^{4}$ cells/well. The growth medium consisted of alpha-minimum essential medium ( $\alpha$-MEM; Invitrogen-Life Technologies, Grand Island, NY) supplemented with $10 \%$ fetal calf serum (GibcoLife Technologies), gentamicin (Gibco) at $50 \mathrm{mg} / \mathrm{mL}$, and fungizone (Gibco) at $0.3 \mathrm{mg} / \mathrm{mL}$, added with ascorbic acid (Gibco-Life Technologies) at $5 \mathrm{mg} / \mathrm{mL}, \beta$-glycerophosphate (Sigma-Aldrich, St. Louis, MO) at $7 \mathrm{mM}$, and dexamethasone (Sigma-Aldrich) at $10^{-7} \mathrm{M}$. The cell cultures were kept at $37^{\circ} \mathrm{C}$ under humidified atmosphere containing 5\% $\mathrm{CO}_{2}$ and $95 \%$ air. The culture medium was changed three times a week.

2.3. Cell Viability. Cell viability was assessed by MTT assay (3-[4,5-dimethylthiazol-2-yl]-2,5-diphenyltetrazolium bromide) 7,10 , and 14 days after the start of the culture. To this end, cells were incubated with $10 \%$ MTT $(5 \mathrm{mg} / \mathrm{mL})$ in culture medium at $37^{\circ} \mathrm{C}$ for 4 hours. The medium was then aspirated from the well, and $1 \mathrm{~mL}$ of isopropanol $(0.04 \mathrm{~N} \mathrm{HCl}$ in isopropanol) was added to each well. The plates were placed on a shaker for 5 minutes and $200 \mu \mathrm{L}$ of this solution was transferred to a 96-well plate. The optical density was read at $570 \mathrm{~nm}$ ( $\mu$ Quant, BioTek Instruments, Winooski, VT, USA).

2.4. Alkaline Phosphatase Assay. Alkaline phosphatase activity was assayed as the release of thymolphthalein from thymolphthalein monophosphate; a commercial kit (Labtest Diagnóstica, MG, Brazil) was employed for this purpose. Briefly, $50 \mathrm{~mL}$ of thymolphthalein monophosphate was mixed with $0.5 \mathrm{~mL}$ of diethanolamine buffer $(0.3 \mu \mathrm{mol} / \mathrm{mL}, \mathrm{pH}$ 10.1), and the resulting solution was kept at $37^{\circ} \mathrm{C}$, for $2 \mathrm{~min}$. After that, $50 \mathrm{~mL}$ of the lysate was added to each of the 
wells, which were kept at $37^{\circ} \mathrm{C}$, for $10 \mathrm{~min}$. Then, $2 \mathrm{~mL}$ of a solution containing $\mathrm{Na}_{2} \mathrm{CO}_{3}(0.09 \mu \mathrm{mol} / \mathrm{mL})$ and $\mathrm{NaOH}$ $(0.25 \mu \mathrm{mol} / \mathrm{mL})$ was added for color development. After $30 \mathrm{~min}$, the absorbance was measured at $590 \mathrm{~nm}$. The alkaline phosphatase activity was calculated from a standard curve with thymolphthalein concentrations ranging from 0.012 to $0.4 \mu \mathrm{mol}$ of thymolphthalein $/ \mathrm{h} / \mathrm{mL}$. Data are expressed as the alkaline phosphatase activity normalized by the total protein assay.

2.5. Mineralized Matrix Formation. Mineralized matrix formation was detected at day 21 by means of Alizarin Red S (Sigma-Aldrich) staining for areas rich in calcium. Attached cells were fixed in $10 \%$ formalin at $4^{\circ} \mathrm{C}$ for $2 \mathrm{~h}$ followed by onehour immersion in alcohol for each increasing concentration (30\%, 50\%, 70\%, and 100\%). The next step was staining with $2 \%$ Alizarin Red S, pH 4.2, for $10 \mathrm{~min}$. The calcium content was evaluated with a colorimetric method formerly described [12]. All biochemical data were compared by the KruskalWallis and Mann-Whitney test. SPSS 17.0 statistical software was used, and differences with $p \leq 0.05$ were considered statistically significant.

2.6. Total RNA Extraction. After 10 days, the total RNA of each culture was extracted with mirVana total RNA isolation kit $^{\circledR}$ (Ambion, NY, USA), according to the manufacturer's instruction. UV spectrophotometry confirmed that the RNA preparations were free of proteins and phenol. RNA degradation was assessed by microfluidic electrophoresis with Agilent 6000 RNA Nano chips, conducted on an Agilent 2100 Bioanalyzer (Agilent Technologies, Santa Clara, CA, USA). Only RNA samples free of proteins and phenol and featuring an RNA Integrity Number (RIN) $\geq 9.0$ were used.

\subsection{Microarray Hybridization}

2.7.1. $m$ RNA Expression Profiling with Agilent $4 \times 44$ K Human Oligoarrays. Changes in gene expression were evaluated with the Agilent one-color (Cy3 fluorochrome) microarray-based gene expression platform according to the manufacturer's instructions. Briefly, $500 \mathrm{ng}$ of the individual total RNA was employed to synthesize double-stranded cDNA and cyanine 3 (Cy3) CTP labeled complementary amplified RNA (cRNA) by means of the Agilent Linear Amplification Kit (Agilent), according to the manufacturer's instructions. By using Agilent human $4 \times 44 \mathrm{~K}$ oligonucleotide microarrays (Agilent), cyanine-labeled complementary RNA was hybridized to microarrays in SureHyb chambers (Agilent) in a rotator oven at $65^{\circ} \mathrm{C}$, for $17 \mathrm{~h}$. Each array contained 44,000 oligonucleotide probes covering the entire human functional genome. The arrays were washed according to the manufacturer's instructions and scanned with an Agilent DNA Microarray scanner.

2.7.2. miRNA Expression Profiling with Agilent $8 \times 15$ K Mouse Oligoarrays. Briefly, the total RNA samples were labeled with $\mathrm{Cy} 3$ by using the Agilent miRNA Complete Labeling and Hybridization Kit (Agilent). To this end, $100 \mathrm{ng}$ of total
RNA was dephosphorylated by incubation with calf intestinal phosphatase at $37^{\circ} \mathrm{C}$ for $30 \mathrm{~min}$, denatured in $100 \%$ DMSO at $100^{\circ} \mathrm{C}$ for $8 \mathrm{~min}$, and labeled with perCp-Cy3 by using T4 ligase at $16^{\circ} \mathrm{C}$ for $2 \mathrm{~h}$. Each labeled RNA sample was hybridized to an individual array on $8 \times 15 \mathrm{~K}$ format Agilent human miRNA array slides. Each array contained probes for 720 human miRNAs. Hybridization was performed in SureHyb chambers (Agilent) at $55^{\circ} \mathrm{C}$ for $20 \mathrm{~h}$, and the arrays were washed according to the manufacturer's instructions and scanned.

2.8. Microarray Data Analysis. The oligo-mRNA and oligomiRNA array slides were scanned with a DNA microarray scanner (Agilent), and the hybridization signals were extracted by using the Agilent Feature Extraction software. The microarray numerical quantitative data were normalized to the 75th percentile and were analyzed through the GeneSpring GX bioinformatics platform (http://www.agilent .com/chem/genespring), according to the default instructions. For mRNA analysis, we used ANOVA statistical test $(p \leq 0.05)$ with a fold change $\geq 2.0$ and, for microRNA analysis, we used ANOVA statistical analysis $(p \leq 0.01)$ with a fold change $\geq 1.5$ [13]. A complete file that provides all of the mRNAs and miRNAs present in the arrays used in this study, as well as the experimental conditions, is available online at a public database (http://www.ebi.ac.uk/arrayexpress/), Array Express accession E-MTAB-3091 (for mRNA hybridization) and E-MTAB-3093 (for microRNA hybridization).

2.9. Oligonucleotide Primer Design and Quantitative RealTime Polymerase Chain Reaction (qRT-PCR). mRNA and microRNA oligoarray data were confirmed by qRT-PCR for five mRNAs (SMURF2, NOTCH1, PHOSPHO1, COL24A1, and FGF1) and six microRNAs (miR-31-3p, miR-134, miR-136-3p, miR-376c-3p, miR-424-5p, and miR-494). The mRNAs or microRNAs were elected on the basis of their expression pattern and biological function associated with the studied model system. The Primer3 web tool (http://biotools.umassmed.edu/bioapps/primer3_www.cgi) was used to select pairs of oligonucleotide primers with an optimal melting temperature of $60^{\circ} \mathrm{C}$. Table 1 lists the oligonucleotide primers used in qRT-PCRs primers for mRNAs and Table 2 lists the accession number and mature sequences for microRNAs. All the qRT-PCRs experiments were conducted in triplicate. One-way ANOVA statistical test was performed with the statistical software GraphPad Prism 5.0 (http://www.graphpad.com/prism/Prism.htm).

\section{Results}

3.1. Scanning Electron Microscopy (SEM). SEM helped to characterize the surface morphology of the titanium discs. The polished control titanium disc displayed smooth surface. The treated titanium discs presented topographic surfaces bearing nanocavities with distinct distribution along the disc surface. The nano+submicrotextured surface group contained the greatest number of nanocavities. Except for surface roughness, the rough microtextured surface group and the 
TABLE 1: Primers used in qRT-PCR reactions and their respective sense and antisense sequences.

\begin{tabular}{|c|c|c|c|}
\hline mRNA symbol & Primer & Sequences & $T_{m}$ \\
\hline \multirow{2}{*}{ SMURF2 } & Forward & $5^{\prime}$-CATGTCTAACCCCGGAGGC-3' & \multirow{2}{*}{$60^{\circ} \mathrm{C}$} \\
\hline & Reverse & $5^{\prime}$-TCCATCAACCACCACCTTAGC-3' & \\
\hline \multirow{2}{*}{ NOTCH1 } & Forward & 5'-TACAAGTGCAACTGCCTGCT-3' & \multirow{2}{*}{$60^{\circ} \mathrm{C}$} \\
\hline & Reverse & $5^{\prime}$-ATAGTCCTCGGATTGCCTGC-3' & \\
\hline \multirow{2}{*}{ PHOSPHO1 } & Forward & 5'-ATACCTCAGCTAGCCСССТT-3' & \multirow{2}{*}{$60^{\circ} \mathrm{C}$} \\
\hline & Reverse & $5^{\prime}$-TGTAGGGACTCTGTTGGCCT-3' & \\
\hline \multirow{2}{*}{ COL24A1 } & Forward & $5^{\prime}$-CCCCACGGCAAAAACGAAAT- $3^{\prime}$ & \multirow{2}{*}{$60^{\circ} \mathrm{C}$} \\
\hline & Reverse & 5'-GCCTCCAAGGCCTAGTTGAT-3' & \\
\hline \multirow{2}{*}{ FGF1 } & Reverse & 5'-ACGGGCTTTTATACGGCTCA-3' & \multirow{2}{*}{$60^{\circ} \mathrm{C}$} \\
\hline & Forward & $5^{\prime}$-ATGGTTCTCCTCCAGCCTTTC-3' & \\
\hline \multirow{2}{*}{ GAPDH } & Forward & $5^{\prime}$-GGGTGTGAACCACGAGAAAT-3' & \multirow{2}{*}{$60^{\circ} \mathrm{C}$} \\
\hline & Reverse & $5^{\prime}$-ССТTCCACAATGCCAAAGTT-3' & \\
\hline
\end{tabular}

nanotextured surface group had quite similar surface images (Figure 1).

3.2. Cell Viability. Cell viability was similar for all the groups at the various time points. The exception was the rough microtextured surface group, which exhibited significantly higher viability at day 7 after the start of the culture $(p \leq 0.05)$ as compared with the other groups (Figure 2).

3.3. Alkaline Phosphatase Activity. In all the experimental groups, the activity of the enzyme alkaline phosphatase, related to the mineralization process, was higher at day 14 after the start of the culture (Figure 3). Among the treated groups, the nanotextured surface group showed the highest alkaline phosphatase production, which was statistically significant as compared with the nano+submicrotextured group at day 14 after the start of the culture $(p \leq 0.05)$.

3.4. Mineralized Nodules. Based on Alizarin Red S quantification, the treated titanium surfaces contained different amounts of calcium deposits. The rough microtextured surface group had the greatest amount of calcium as compared with the control group and the nanotextured surface group $(p \leq 0.05)$ (Figure 4).

3.5. Analysis of Differentially Expressed mRNAs. A total of 716 genes showed fold change $\geq 2.0$ and $p \leq 0.05$ (Figure 5). Table 3 displays differentially expressed genes associated with osteogenesis, cell adhesion, apoptosis, cell growth, and cell differentiation. Table 4 depicts the differences in the expression of these genes as a function of the titanium surface topography.

3.6. Analysis of Differentially Expressed MicroRNAs. According to the results, $32 \mathrm{miRNAs}$ showed fold change $\geq 1.5$ and $p \leq 0.01$ (Figure 6). Table 5 presents differentially expressed miRNAs associated with osteogenesis, apoptosis, and cell growth. Table 6 summarizes the different expression of these miRNAs in the studied titanium surfaces.
3.7. mRNA Data Confirmation by Real-Time Quantitative $P C R$. qRT-PCR confirmed five differentially expressed mRNAs in the experimental groups; these mRNAs had been previously detected by oligomicroarray analysis (Table 5). The confirmed mRNAs are associated with apoptosis (NOTCH1), bone tissue and bone tissue mineralization (SMURF2, NOTCH1, and PHOSPHO1), cell adhesion (COL24A1 and FGF1), and cell proliferation (FGF1) (http://geneontology.org/, accessed 20/02/2014) (Figure 7).

3.8. MicroRNA Data Confirmation by Real-Time Quantitative $P C R$. Real-time quantitative PCR allowed analysis of six miRNAs that were differentially expressed in the experimental groups: miR-31-3p, miR-134, miR-136-3p, miR-376C3p, miR-494, and miR-424-5p (Table 6). These miRNAs are associated with several functions like apoptosis (miR-134 and miR-494), bone mineralization (miR-31-3p, miR-136$3 p$, miR-376C-3p, and miR-424-5p), and cell growth and proliferation (miR-134) (http://geneontology.org/, accessed 02/20/2014) (Figure 8).

\section{Discussion}

Several studies aimed at analyzing and comparing the response of different cell types in contact with titanium surfaces modified by numerous methods [14]. In the present study, it was observed that oxidative nanopatterning of titanium engenders micro- and nanotextured surfaces that influence the metabolism of human alveolar bone cells. It has been shown that [15] nanotextured titanium surfaces generated by this chemical method promote osteoblast proliferation, making this a promising technique for the regulation of cellular activities in biological environments. A previous investigation revealed that chemical oxidation with $\mathrm{H}_{2} \mathrm{SO}_{4}{ }^{\text {conc }} / \mathrm{H}_{2} \mathrm{O}_{2}{ }^{\text {aq }}$ solution is an efficient tool to achieve various physical and chemical configurations on titanium surface, demonstrating that, by varying etching parameters such as solution composition, temperature, and exposure time, it is possible to modify the topography, oxide thickness, and wettability of commercially pure titanium [5]. In the 


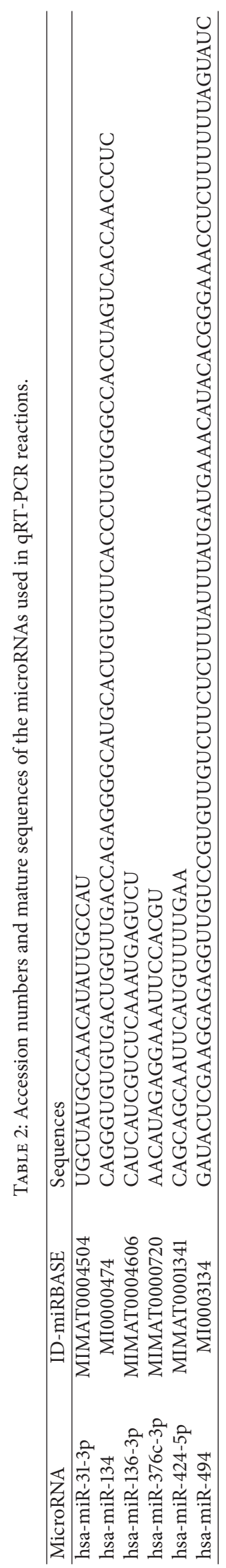


TABLE 3: Genes differentially expressed among the following groups: control, nanotexture, nano+submicrotexture, and rough microtexture after 10 days of culture, with associated functions according to the Gene Ontology database.

\begin{tabular}{lcccc}
\hline Osteogenesis & Cell adhesion & Apoptosis & Cell growth and proliferation & Cell differentiation \\
\hline ATP6VOA4 & AMICA1 & AIPL1 & E2F5 & C10orf27 \\
CDX1 & SORBS1 & LUC7L3 & KIAA1109 & CYP24A1 \\
CYP27B1 & NRXN1 & ERBB3 & LGI1 & NANOG \\
SMURF2 & PCDHA11 & NOTCH1 & CYP27B1 & HSF4 \\
NOTCH1 & NRXN1 & PSMD3 & GRIN2A & LAMC3 \\
PHOSPHO1 & FGF1 & BTK & KDR & MMP7 \\
& ERBB3 & PTPRC & PDE3A & CENPF \\
& PCDHB10 & ABCB9 & FGF1 \\
& EPB41L5 & KDR & MECOM \\
\end{tabular}

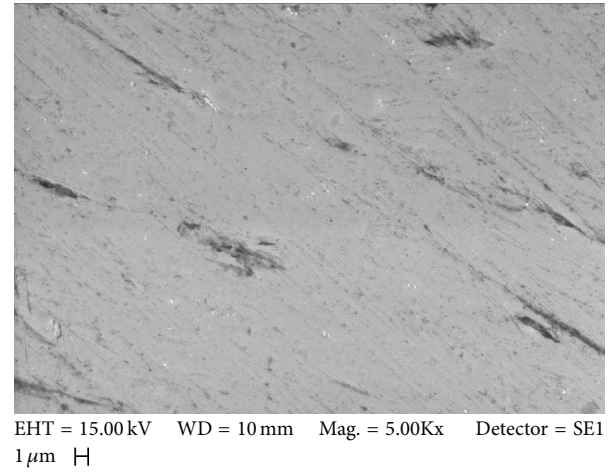

(a)

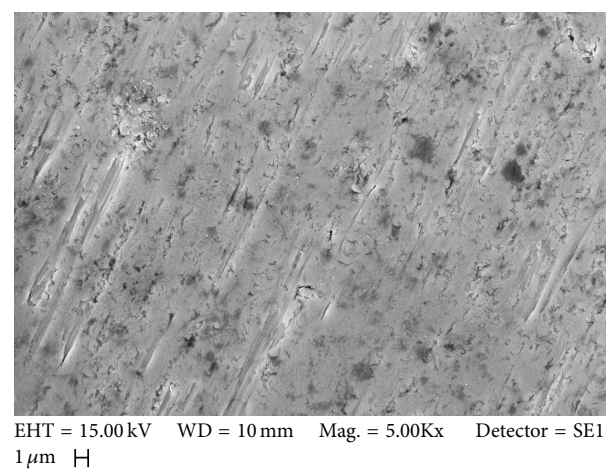

(c)

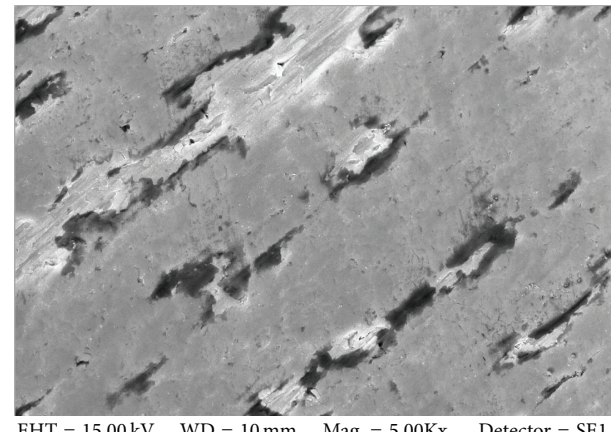

EHT $=15.00 \mathrm{kV} \quad W D=10 \mathrm{~mm} \quad$ Mag. $=5.00 \mathrm{Kx} \quad$ Detector $=\mathrm{SE} 1$ $1 \mu \mathrm{m} \mathrm{H}$

(b)

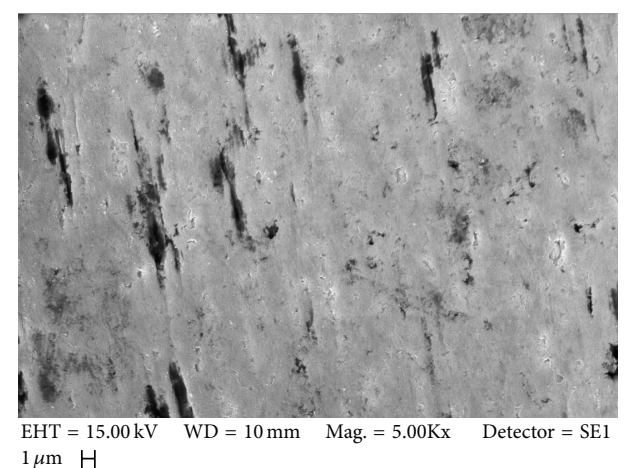

(d)

FIGURE 1: Scanning electron microscopy of different titanium surfaces: (a) control surface, (b) nanotextured surface, (c) nano+submicrotextured surface, and (d) rough microtextured surface.

present study, by using these parameters, we showed that oxidative nanopatterning promotes similar responses for cell viability for all groups at all time points tested, except for the rough microtexture, which showed significantly higher viability compared to the other groups after 7 days. Besides viability, biochemical assays like alkaline phosphatase activity are important to associate biomaterials topography with cell differentiation and osseointegration [8]. The ALP is among the first functional genes expressed in the calcification process, so it is possible that one of their roles in the mineralization process occurs at an early stage [16]. Nevertheless, the increased production of alkaline phosphatase was observed just after 14 days of culture in all experimental groups. Among the etched surfaces, cells cultured on nanotextured titanium 
TABLE 4: Relative expression levels of mRNAs differentially expressed among control (C), nanotexture (N), nano+submicrotexture (NS), and rough microtexture (MR) groups after 10 days of culture. FC: fold change.

\begin{tabular}{|c|c|c|c|c|c|c|}
\hline Gene & $\begin{array}{c}\mathrm{C} \text { versus } \mathrm{MR} \\
\mathrm{FC}\end{array}$ & $\begin{array}{c}\text { C versus } S \\
\text { FC }\end{array}$ & $\begin{array}{c}\text { C versus } \mathrm{N} \\
\mathrm{FC} \\
\end{array}$ & $\begin{array}{c}\text { MR versus NS } \\
\text { FC }\end{array}$ & $\begin{array}{c}\text { MR versus } \mathrm{N} \\
\mathrm{FC}\end{array}$ & $\begin{array}{c}\text { NS versus } \mathrm{N} \\
\mathrm{FC}\end{array}$ \\
\hline ABCB9 & 2,423 & 1,045 & 1,106 & $-2,319$ & $-2,191$ & 1,059 \\
\hline AIPL1 & 1,055 & $-2,369$ & 1,164 & $-2,500$ & 1,103 & 2,758 \\
\hline AMICA1 & 2,308 & 1,693 & 2,524 & $-1,364$ & 1,094 & 1,491 \\
\hline ATP6V0A4 & $-5,137$ & $-1,532$ & $-3,833$ & 3,353 & 1,340 & $-2,502$ \\
\hline BTK & $-4,130$ & $-1,516$ & $-6,530$ & 2,725 & $-1,581$ & $-4,308$ \\
\hline C10orf27 & $-2,049$ & $-1,277$ & $-1,827$ & 1,605 & 1,122 & $-1,431$ \\
\hline CD28 & $-3,104$ & $-1,478$ & $-2,068$ & 2,101 & 1,501 & $-1,400$ \\
\hline CDX1 & $-2,178$ & $-1,136$ & $-1,572$ & 1,918 & 1,386 & $-1,384$ \\
\hline CENPF & 2,296 & 1,639 & 1,574 & $-1,401$ & $-1,459$ & $-1,041$ \\
\hline COL24A1 & 2,308 & 1,076 & $-1,584$ & $-2,144$ & $-3,655$ & $-1,705$ \\
\hline CYP27B1 & 2,325 & $-1,042$ & 4,278 & $-2,422$ & 1,840 & 4,457 \\
\hline E2F5 & 2,572 & 1,012 & 3,240 & $-2,542$ & 1,260 & 3,203 \\
\hline EPB41L5 & 2,725 & 1,796 & 2,440 & $-1,518$ & $-1,117$ & 1,359 \\
\hline ERBB3 & $-2,036$ & 1,391 & $-1,934$ & 2,832 & 1,052 & $-2,691$ \\
\hline FGF1 & 1,929 & 1,309 & 2,792 & $-1,473$ & 1,447 & 2,132 \\
\hline GPAM & 3,438 & $-1,467$ & 2,420 & $-5,045$ & $-1,421$ & 3,551 \\
\hline GRIN2A & 2,065 & $-1,066$ & 2,005 & $-2,202$ & $-1,030$ & 2,138 \\
\hline HSF4 & $-2,358$ & $-2,213$ & $-1,331$ & 1,066 & 1,772 & 1,663 \\
\hline KDR & 1,563 & $-1,134$ & 2,118 & $-1,772$ & 1,355 & 2,401 \\
\hline KIAA1109 & 1,948 & 1,340 & 2,146 & $-1,453$ & 1,102 & 1,602 \\
\hline LAMC3 & 2,138 & 2,921 & 2,086 & 1,366 & $-1,025$ & $-1,400$ \\
\hline LGI1 & 3,533 & 1,452 & 4,124 & $-2,433$ & 1,167 & 2,839 \\
\hline LUC7L3 & 2,064 & 1,673 & 1,507 & $-1,234$ & $-1,370$ & $-1,110$ \\
\hline MAPT & 6,567 & 1,653 & 4,711 & $-3,973$ & $-1,394$ & 2,849 \\
\hline MECOM & $-2,952$ & $-3,421$ & $-8,666$ & $-1,159$ & $-2,936$ & $-2,533$ \\
\hline MMP7 & 2,731 & 1,120 & 2,208 & $-2,438$ & $-1,237$ & 1,972 \\
\hline NANOG & 3,365 & 2,137 & 3,791 & $-1,575$ & 1,127 & 1,774 \\
\hline NCKAP1L & $-1,722$ & $-2,257$ & $-1,736$ & $-1,311$ & $-1,008$ & 1,300 \\
\hline NOTCH1 & 1,306 & $-1,812$ & 1,416 & $-2,367$ & 1,084 & 2,565 \\
\hline NRXN1 & 2,462 & 1,377 & $-1,203$ & $-1,788$ & $-2,963$ & $-1,657$ \\
\hline PCDHA11 & 2,074 & $-1,266$ & 2,259 & $-2,626$ & 1,089 & 2,859 \\
\hline PCDHB10 & 3,328 & $-1,025$ & 3,581 & $-3,411$ & 1,076 & 3,669 \\
\hline PDE3A & $-3,260$ & 1,121 & $-3,908$ & 3,656 & $-1,199$ & $-4,382$ \\
\hline PHOSPHO1 & $-2,024$ & $-1,214$ & $-1,757$ & 1,667 & 1,152 & $-1,448$ \\
\hline PSMD3 & $-2,075$ & $-2,131$ & $-1,353$ & $-1,027$ & 1,533 & 1,574 \\
\hline PTPRC & 1,453 & $-1,392$ & 1,475 & $-2,022$ & 1,016 & 2,054 \\
\hline PTPRK & $-3,909$ & $-1,952$ & 1,034 & 2,002 & 4,040 & 2,018 \\
\hline RNF7 & 2,803 & 1,199 & 1,387 & $-2,339$ & $-2,021$ & 1,157 \\
\hline SMURF2 & 1,193 & $-2,344$ & $-1,142$ & $-2,797$ & $-1,362$ & 2,053 \\
\hline SORBS1 & $-3,880$ & $-3,008$ & $-3,342$ & 1,290 & 1,161 & $-1,111$ \\
\hline SOX21 & 2,006 & 1,583 & 2,829 & $-1,267$ & 1,411 & 1,787 \\
\hline UTRN & $-1,602$ & $-1,884$ & $-2,062$ & $-1,176$ & $-1,287$ & $-1,094$ \\
\hline
\end{tabular}

discs showed the highest ALP activity, which was statistically significant compared to the NS group after 14 days. By exploiting microarray methodology, we found 716 differentially expressed genes of alveolar bone osteoblastic cells in contact with different titanium surfaces, most of them associated with the process of osteogenesis (e.g., mineralization, adhesion, apoptosis, proliferation, and differentiation). Among them, it was observed that NOTCH1 gene increased its expression in nano+submicrotexture surfaces when compared to the other experimental conditions. NOTCH is a key target in the osteoblastic cells and in osteoclastogenesis, as well as skeletal development and bone remodeling [17]. NOTCH is 
TABLE 5: MicroRNAs differentially expressed among control, nanotexture, nano+submicrotexture, and rough microtexture groups after 10 days of culture, with associated functions according to Gene Ontology database.

\begin{tabular}{lcc}
\hline Osteogenesis & Apoptosis & Cell growth and proliferation \\
\hline hsa-miR-424-5p & hsa-miR-494 & hsa-miR-134 \\
hsa-miR-136-3p & hsa-miR-134 & \\
hsa-miR-136-5p & & \\
hsa-miR-31-3p & \\
hsa-miR-376c-3p & \\
hsa-miR-19b-3p & \\
hsa-miR-21-3p & \\
hsa-miR-21-5p & \\
hsa-miR-218-5p & \\
hsa-miR-29b-3p & & \\
\hline
\end{tabular}

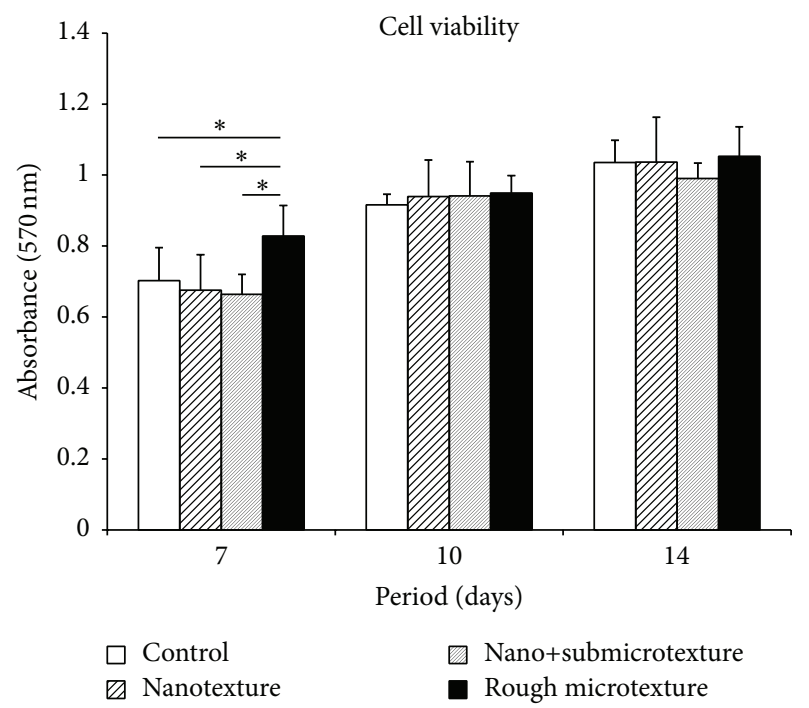

Figure 2: Cell viability of human alveolar osteoblastic cells at days 7,10 , and 14 of the start of the culture on polished titanium discs and on titanium surfaces etched by oxidative nanopatterning. MannWhitney test for ${ }^{*} p \leq 0.05$.

an additional pathway that is triggered early in the response to modified titanium surfaces, as it would be involved in the process of osteogenesis and in vivo bone formation and healing [18]. These findings are in agreement with our microarray results, despite the fact that qRT-PCR validation method showed similar responses only in the increased expression between $\mathrm{C} / \mathrm{MR}$ and $\mathrm{C} / \mathrm{N}$ groups. Another differentially expressed gene was PHOSPHO1, which showed higher expression in cells adhering onto rough microtexture. This gene codifies a protein involved in the initial deposition of hydroxyapatite crystals in early events of matrix mineralization [19]. Interestingly, the microarray data were in good agreement with our biochemical results, where the cultures in contact with rough microtexture showed higher calcium deposition, despite not being similar to qRTPCR validation method. SMURF2 interacts with SMADS and induces ubiquitin-mediated degradation, preventing the

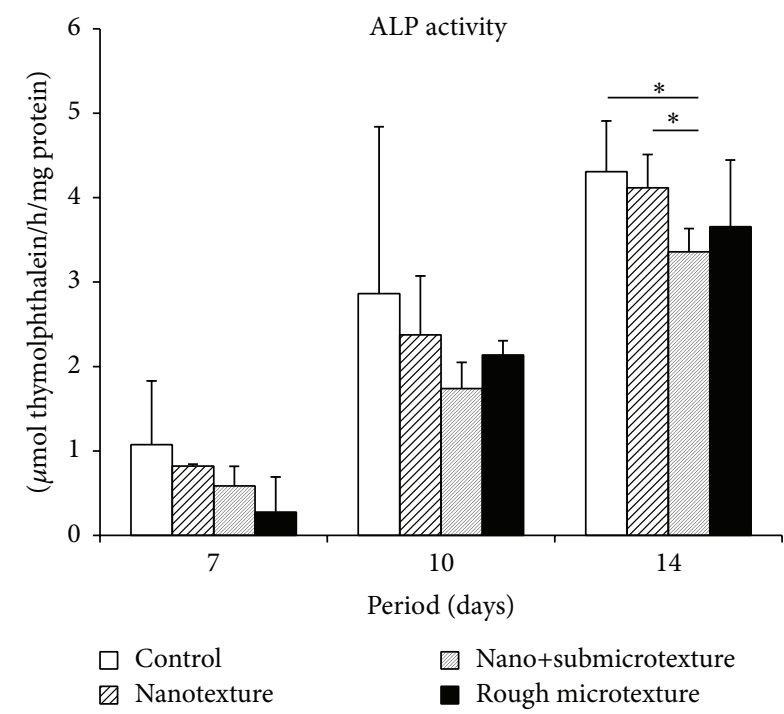

FIGURE 3: Alkaline phosphatase (ALP) activity of human alveolar osteoblastic cells after 7, 10, and 14 days of the start of the culture on polished titanium discs and on titanium surfaces etched by oxidative nanopatterning. Mann-Whitney test for ${ }^{*} p \leq 0.05$.

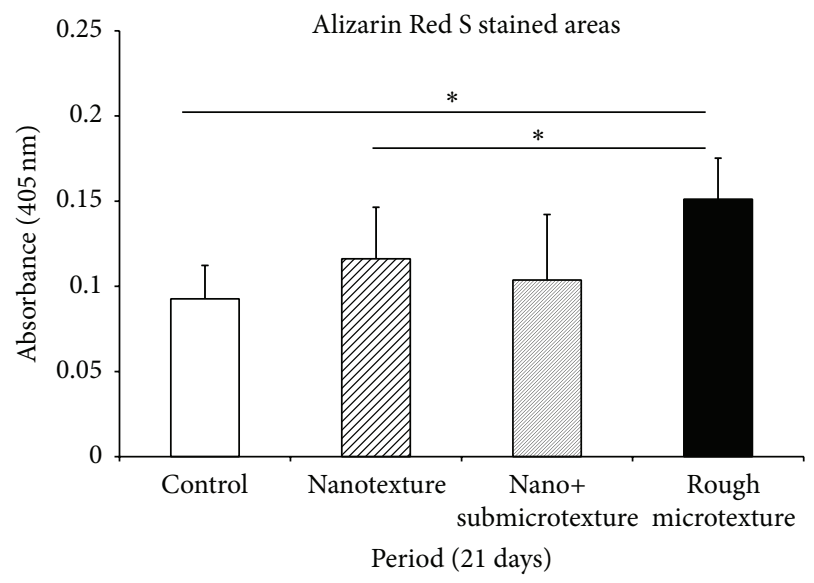

FIgURE 4: Quantitative analysis of Alizarin Red S stained areas of calcified nodules 21 days after the start of the culture on polished titanium discs and on titanium surfaces etched by oxidative nanopatterning. Mann-Whitney test for ${ }^{*} p \leq 0.05$.

signaling of TGF- $\beta$ (transforming growth factor) and BMP (bone morphogenetic protein). Both the TGF- $\beta$ and BMP are multifunctional proteins important for regulation of proliferation, differentiation, migration, and apoptosis [20]. Microarray data showed a higher expression of SMURF2 in cells adhering onto nano+submicrotexture surfaces when comparing to the other etched surfaces, whereas qRT-PCR revealed a higher expression of cells seeded on nanotextured titanium. These results suggest that the consequently lower expression of SMURF2 in cells seeded on MR surfaces might influence positively the osteoblast differentiation and Runx2 stability, promoting cell-biomaterial interaction, as seen after 7 and 21 days in MTT and Alizarin Red S staining assays, respectively. Another gene important to cell adhesion and 
TABLE 6: Relative expression levels of microRNAs differentially expressed among control (C), nanotexture (N), nano+submicrotexture (NS), and rough microtexture (MR) groups after 10 days of culture. FC: fold change.

\begin{tabular}{|c|c|c|c|c|c|c|}
\hline miRNA & $\begin{array}{c}\text { C versus MR } \\
\text { FC }\end{array}$ & $\begin{array}{c}\text { C versus NS } \\
\text { FC } \\
\end{array}$ & $\begin{array}{c}\text { C versus } \mathrm{N} \\
\text { FC } \\
\end{array}$ & $\begin{array}{c}\text { MR versus NS } \\
\text { FC }\end{array}$ & $\begin{array}{c}\text { MR versus } \mathrm{N} \\
\text { FC }\end{array}$ & $\begin{array}{c}\text { NS versus } \mathrm{N} \\
\mathrm{FC}\end{array}$ \\
\hline hsa-miR-101-3p & 2,635 & 1,033 & 1,036 & $-2,551$ & $-2,542$ & 1,003 \\
\hline hsa-miR-106b-5p & 1,511 & $-1,018$ & 1,000 & $-1,539$ & $-1,510$ & 1,019 \\
\hline hsa-miR-1246 & 1,173 & 1,963 & 1,133 & 1,674 & $-1,036$ & $-1,733$ \\
\hline hsa-miR-1290 & 1,057 & 2,161 & 1,113 & 2,045 & 1,053 & $-1,941$ \\
\hline hsa-miR-134 & $-1,478$ & $-1,119$ & 1,025 & 1,321 & 1,515 & 1,147 \\
\hline hsa-miR-136-3p & 182,144 & $-1,044$ & 4,031 & $-190,073$ & $-45,188$ & 4,206 \\
\hline hsa-miR-136-5p & 67,552 & 1,001 & $-1,132$ & $-67,496$ & $-76,442$ & $-1,133$ \\
\hline hsa-miR-15a-5p & 1,633 & 1,009 & $-1,027$ & $-1,619$ & $-1,678$ & $-1,036$ \\
\hline hsa-miR-1826_v15.0 & $-1,174$ & 1,173 & 1,299 & 1,377 & 1,525 & 1,107 \\
\hline hsa-miR-1914-3p & $-1,401$ & $-1,001$ & 1,186 & 1,399 & 1,662 & 1,188 \\
\hline hsa-miR-193a-3p & 2,493 & $-1,059$ & $-1,021$ & $-2,640$ & $-2,546$ & 1,037 \\
\hline hsa-miR-19a-3p & 2,033 & $-1,060$ & $-1,069$ & $-2,154$ & $-2,173$ & $-1,009$ \\
\hline hsa-miR-19b-3p & 1,544 & $-1,035$ & $-1,053$ & $-1,598$ & $-1,627$ & $-1,018$ \\
\hline hsa-miR-21-3p & 1,402 & $-1,205$ & $-1,097$ & $-1,688$ & $-1,538$ & 1,098 \\
\hline hsa-miR-21-5p & 1,782 & $-1,000$ & $-1,000$ & $-1,782$ & $-1,782$ & $-1,000$ \\
\hline hsa-miR-218-5p & 1,931 & 1,054 & $-1,005$ & $-1,832$ & $-1,940$ & $-1,059$ \\
\hline hsa-miR-26b-5p & 1,635 & 1,036 & 1,024 & $-1,579$ & $-1,598$ & $-1,012$ \\
\hline hsa-miR-27a-3p & 1,588 & $-1,000$ & $-1,000$ & $-1,588$ & $-1,588$ & $-1,000$ \\
\hline hsa-miR-29b-3p & 2,128 & 1,083 & 1,014 & $-1,964$ & $-2,098$ & $-1,068$ \\
\hline hsa-miR-301a-3p & 1,685 & $-1,041$ & 1,034 & $-1,754$ & $-1,630$ & 1,076 \\
\hline hsa-miR-31-3p & 1,464 & $-1,092$ & $-1,120$ & $-1,599$ & $-1,640$ & $-1,026$ \\
\hline hsa-miR-374a-5p & 1,868 & $-1,083$ & $-1,093$ & $-2,023$ & $-2,041$ & $-1,009$ \\
\hline hsa-miR-376a-3p & 1,411 & $-1,081$ & $-1,046$ & $-1,526$ & $-1,477$ & 1,033 \\
\hline hsa-miR-376b-3p & 2,361 & $-1,105$ & 1,085 & $-2,608$ & $-2,176$ & 1,199 \\
\hline hsa-miR-376c-3p & 1,424 & $-1,141$ & $-1,077$ & $-1,625$ & $-1,533$ & 1,060 \\
\hline hsa-miR-377-3p & 1,754 & $-1,019$ & 1,005 & $-1,788$ & $-1,745$ & 1,025 \\
\hline hsa-miR-424-5p & 2,125 & 1,051 & 1,043 & $-2,021$ & $-2,038$ & $-1,008$ \\
\hline hsa-miR-450a-5p & 202,710 & 1,121 & 3,964 & $-180,812$ & $-51,138$ & 3,536 \\
\hline hsa-miR-494 & $-1,416$ & 1,006 & 1,120 & 1,424 & 1,585 & 1,113 \\
\hline hur_5 & $-1,357$ & 1,120 & 1,132 & 1,519 & 1,537 & 1,011 \\
\hline miRNABrightCorner30 & 1,657 & 2,170 & 1,197 & 1,309 & $-1,385$ & $-1,813$ \\
\hline mr_1 & $-1,519$ & $-1,000$ & $-1,000$ & 1,519 & 1,519 & $-1,000$ \\
\hline
\end{tabular}

cell proliferation is FGF1, which plays a crucial role in the proliferation and differentiation of osteoblasts [21]. FGF1 expression in microarray was increased in cells cultivated on control and NS surfaces, whereas qRT-PCR showed higher expression in cells seeded on nanotextured discs. Our biochemical assays on proliferation and viability did not reveal differences on cell adhesion and proliferation. COL24A1 gene proved to have some control on osteoblast differentiation and mineralization, through interaction with integrin $\beta 3$ and the transforming growth factor beta (TGF- $\beta$ )/SMADS signaling pathway [22]. It was found that COL24A1 gene is activated at the same time as the gene encoding osteocalcin, and its expression increases gradually as osteoblasts begin to deposit mineralized matrix [23]. Our microarray analysis showed increased expression in cells seeded on nanotexture titanium discs when compared to the other etched surfaces, which is in agreement with other investigations [24].

It has been observed that during bone formation several miRNAs participate both in early and in late stage of osteoblast differentiation regulating pathways in vivo [25]. The present study identified 32 miRNAs differentially expressed among the experimental groups. In particular, these miRNAs are involved in mineralization, apoptosis, and regulation of cell growth and proliferation. We showed that miR-136-3p exhibits a lower expression in cells seeded on rough microtexture surfaces when compared to $\mathrm{N}$ and $\mathrm{MR}$ 


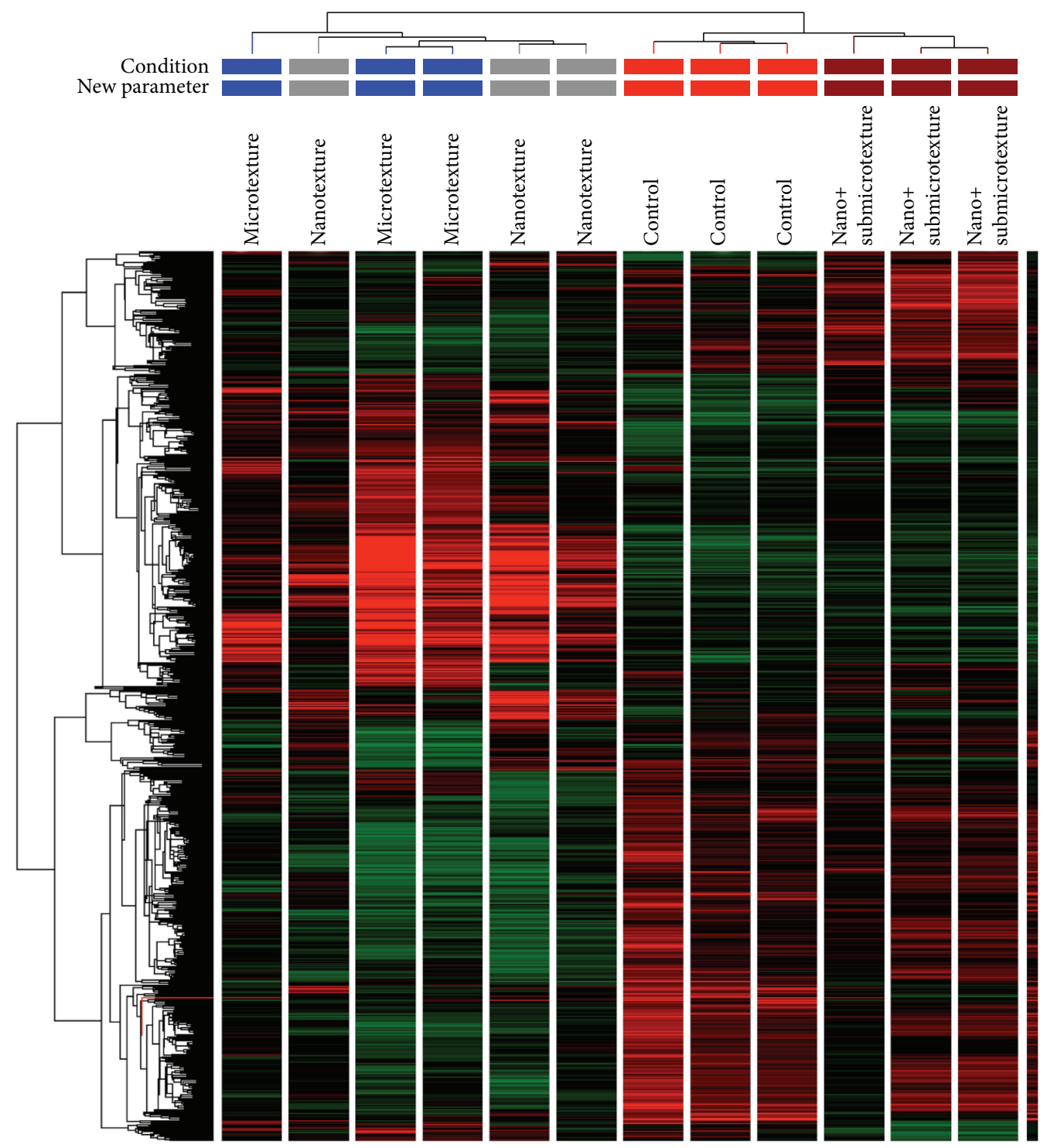

FIGURE 5: Hierarchical clustering of 716 differentially expressed genes of human alveolar osteoblastic cells on polished and etched titanium surfaces (nanotextured, nano+submicrotextured, and rough microtextured) 10 days after the start of the culture. Red: upregulation; green: downregulation; black: unmodulated.

surfaces in microarray and qRT-PCR data. The literature shows that miR-136 promotes downregulation in osteoblast differentiation [26], suggesting that in the present work this microRNA benefited the deposition of extracellular matrix in MR group as seen in our biochemical results. On the other hand, the higher expression of miR-134 in MR group revealed by microarray data may have resulted in diminished cell adhesion, as some microRNAs promote regulation of integrins, which are transmembrane cell adhesion receptors and have great importance for the unity of the cell to extracellular matrix, as well as participating in interactions between cells [26]. Poitz et al. [27] demonstrated that miR-134 promoted $\beta 1$ integrin negative regulation, resulting in reduction of adhesion to fibronectin of mesenchymal stem cells (MSCs). Despite that, our MTT assay does not show any decrease in the viability of cells seeded on MR surface. Microarray and qRT-PCR methods also showed an increased expression of miR-494 in rough microtexture when compared to nanotexture. This microRNA mediates apoptosis and necrosis in different cell types [28], but this effect was not seen in the present work, with all cells seeded on etched surfaces showing similar or higher viability than control cells. We observed involvement of miR-31 in the regulation of transcription factor osterix in human bone marrow cells (MSCs) differentiated into osteoblasts [29]. Osterix is a key regulator of bone cell differentiation and plays an essential role in bone homeostasis [30]. Deng et al. [31] also observed that overexpression of miR-31 significantly reduced the expression of osteogenic transcription factors like OPN, BSP, OCN, and OSX, but not Runx2. Our data from microarray analysis as well as from qRT-PCR revealed that miR-31-3p had an increase in its expression in cells seeded on nanotexturized surface and 


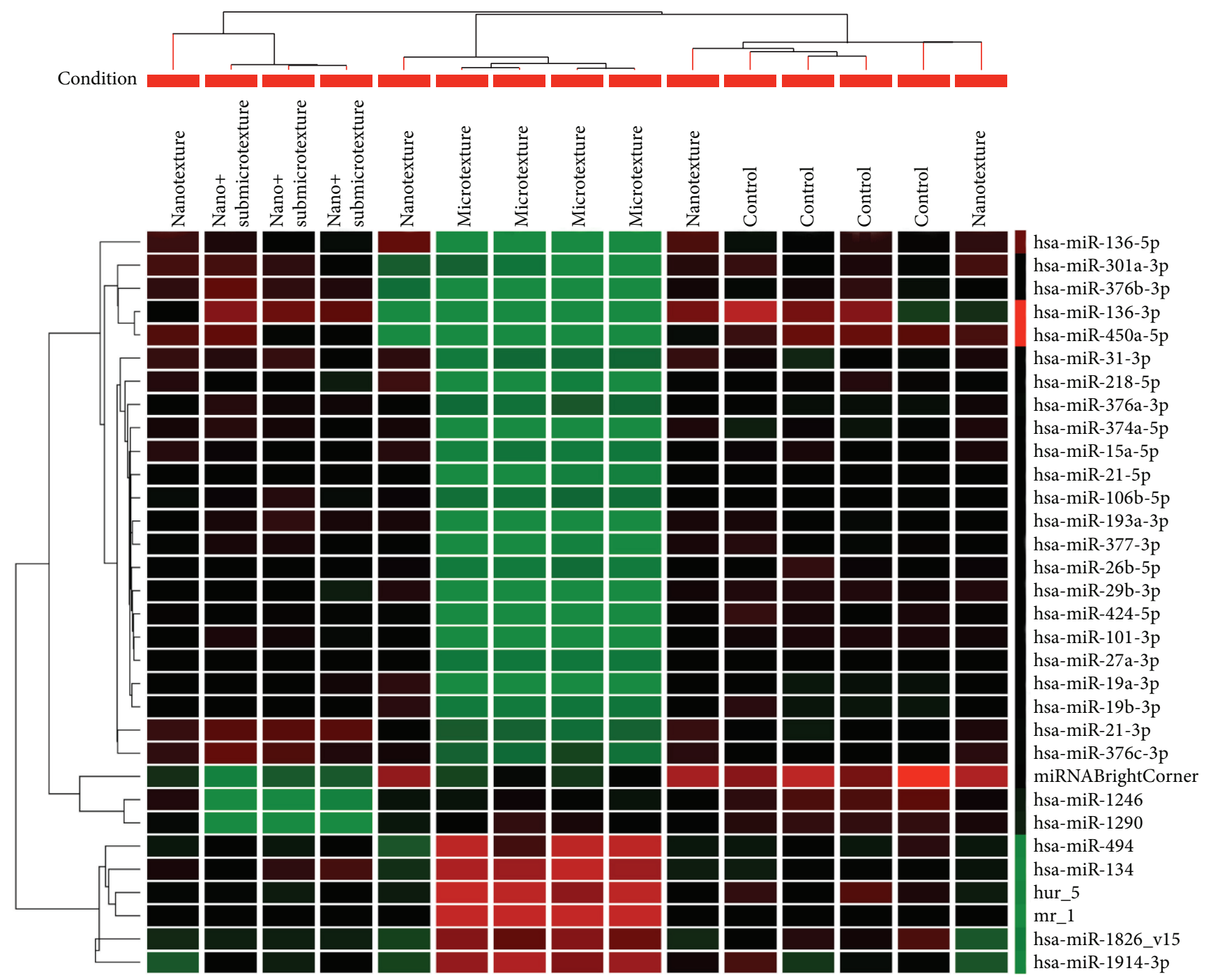

FIGURE 6: Hierarchical clustering of 32 differentially expressed microRNAs of human alveolar osteoblastic cells on polished and etched titanium surfaces (nanotextured, nano+submicrotextured, and rough microtextured) 10 days after the start of the culture. Red: upregulation; green: downregulation; black: unmodulated.

a decrease on MR titanium discs. In the same way, cells on rough microtextured surface showed lower expression of miR-424-5p when compared to other etched surfaces whereas nanotextured surface revealed higher expression, confirmed by microarray and qRT-PCR. miR-424 also has regulatory roles in the differentiation of human bone marrow cells into osteoblasts [32] and these results may have contributed to the enhanced cell differentiation seen in the first group by means of ALP activity after 14 days. Other miRNAs, which influence bone metabolism, were differentially expressed in our study, such as miR-19b, miR-21, miR-218, and miR-29b.

The qRT-PCR method helps to validate the microarray data. In this study, we validated microarray methodology by conducting qRT-PCR of five genes and six microRNAs elected on the basis of their expression pattern and of their association with osteogenesis. However, qRT-PCR did not confirm all the results obtained by microarray analysis, which is shown also by other studies [33, 34]. According to the literature, differences between data obtained by the two methods may occur because microarray hybridization protocol might avoid the detection of subtle differences in gene expression, which could be detected by qRT-PCR technique [35]. Another cited reason is that these differences could occur as a consequence of increased separation between the locations of the PCR primers and the microarray probes [36]. Besides, microarray and qRT-PCR protocols perform normalization by different software (i.e., global gene expression and endogenous control, resp.) [37].

The results shown in this investigation reveal that several other mRNAs and miRNAs can be modulated as a consequence of surface modification, and more studies should be addressed to elucidate their role in osteoblast metabolism. In conclusion, it has been shown that oxidative nanopatterning of titanium surface influences alveolar bone osteoblastic cell metabolism and modulates the expression of genes encoding proteins that are important for osteogenesis. 
COL24A1
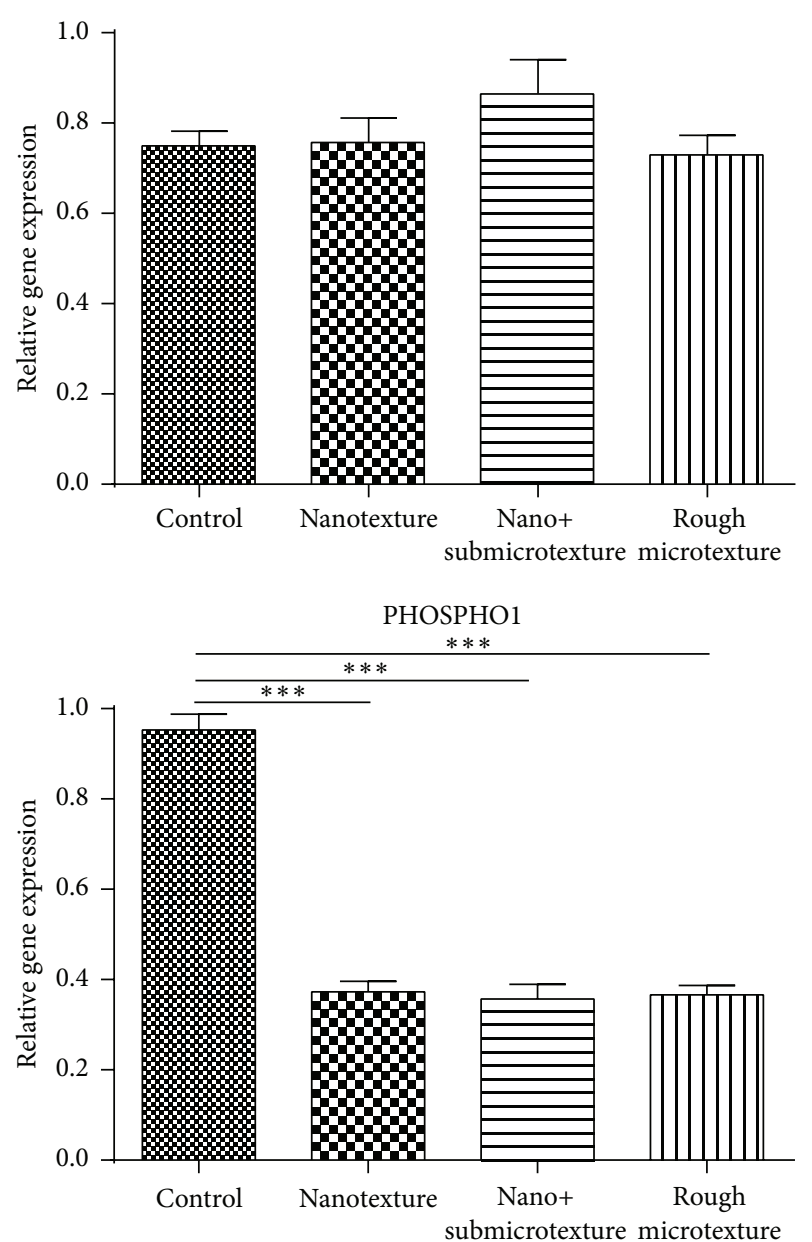
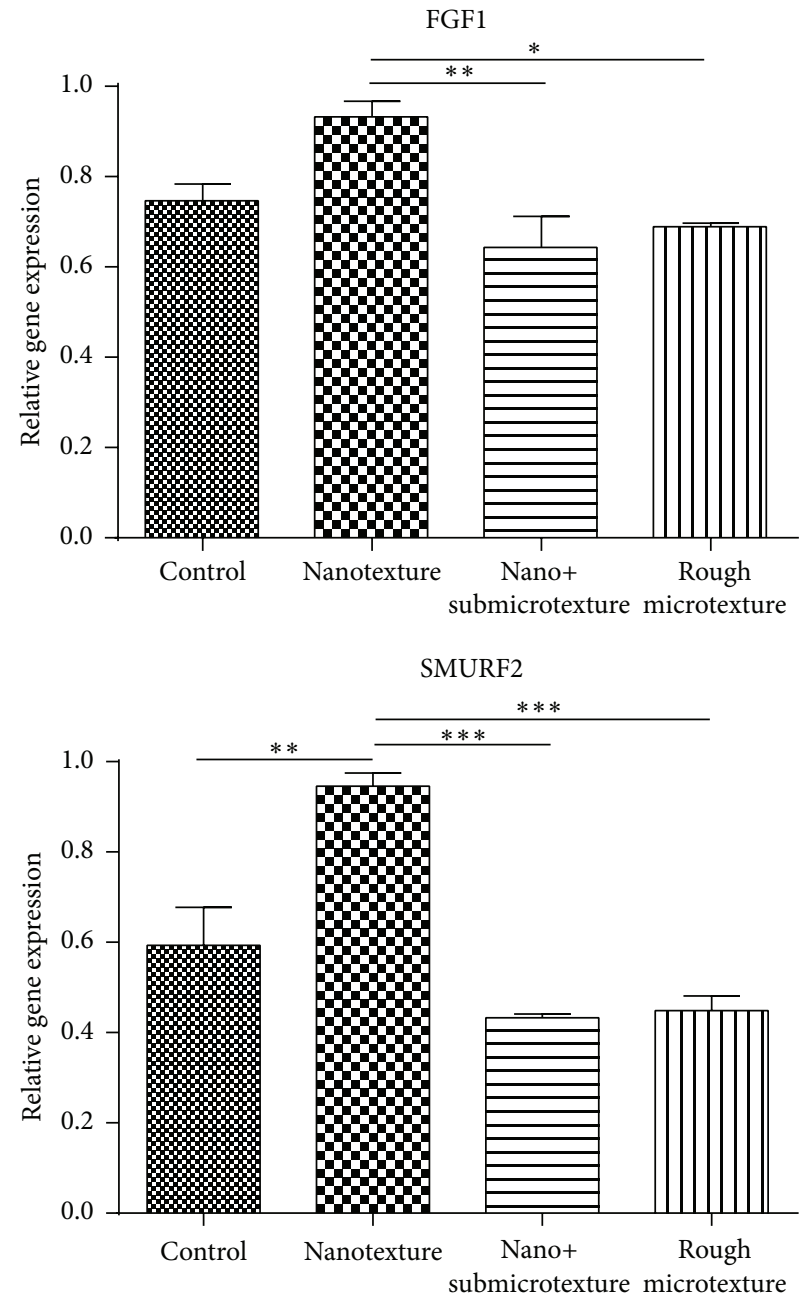

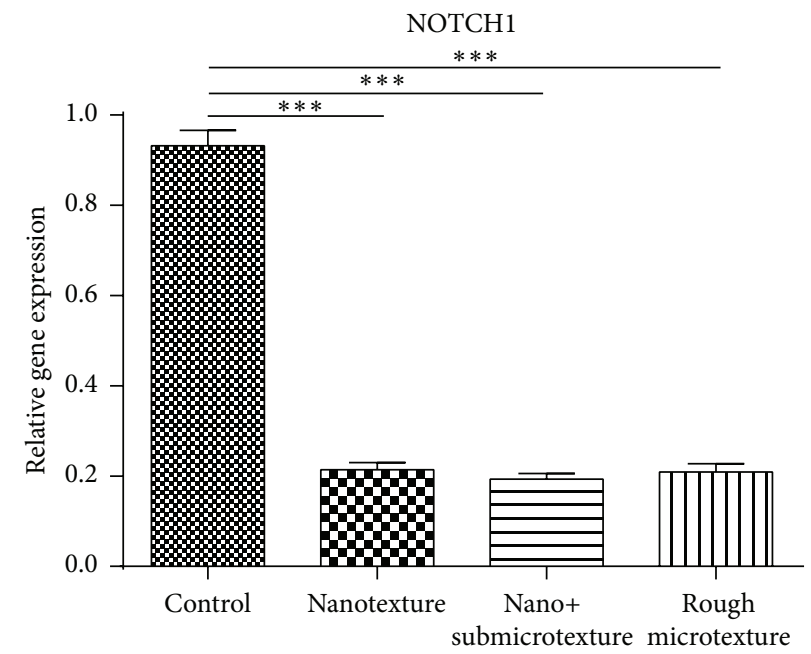

FIGURE 7: Quantitative expression of mRNAs of human alveolar osteoblastic cells on polished and etched titanium surfaces (nanotextured, nano+submicrotextured, and rough microtextured). Statistical analysis by Tukey Multiple Comparison Test; ${ }^{*} p<0.05,{ }^{* *} p<0.01$, and ${ }^{* * *} p<0.001$. 

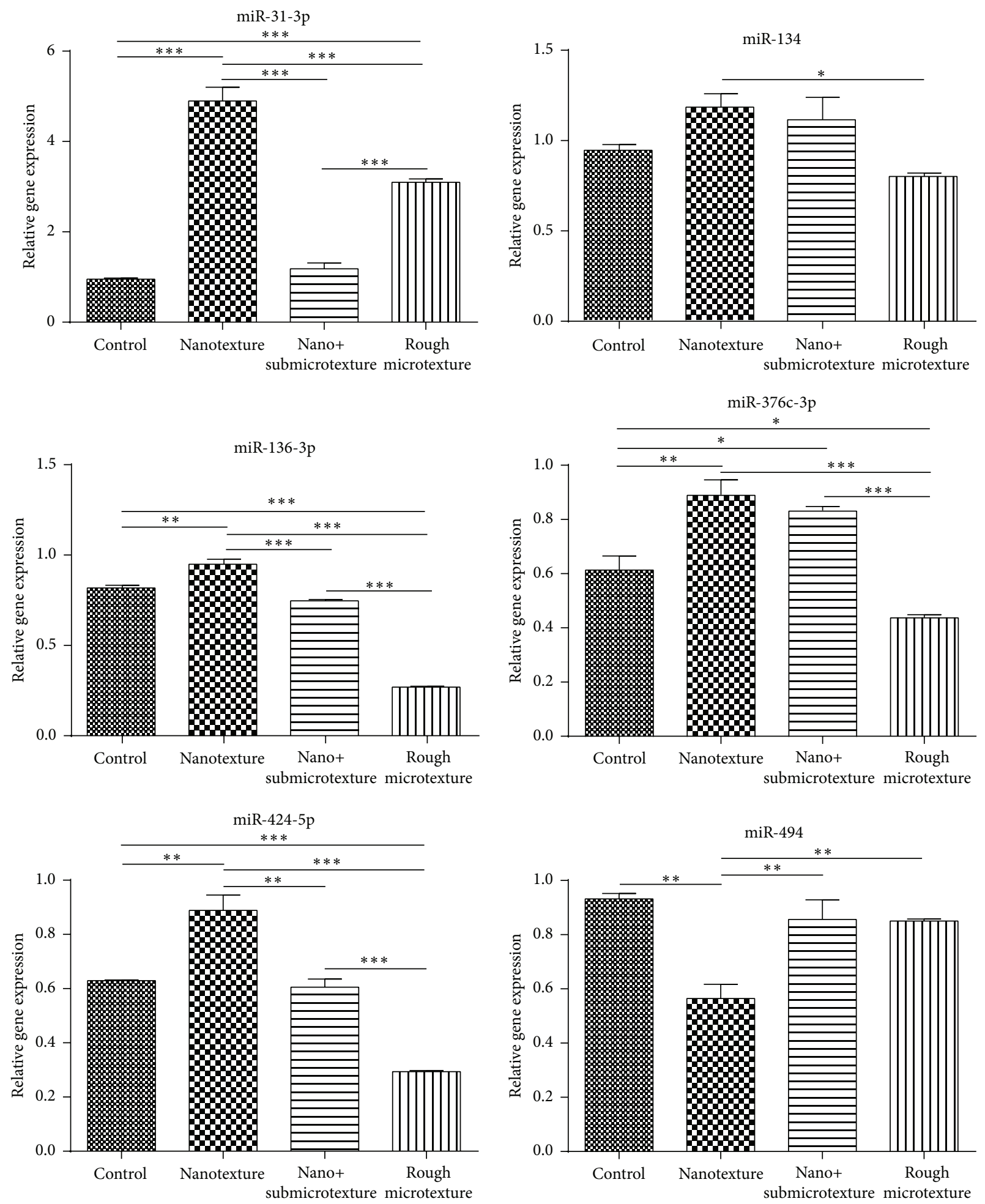

FIGURE 8: Quantitative expression of miRNAs of human alveolar osteoblastic cells on polished and etched titanium surfaces (nanotextured, nano+submicrotextured, and rough microtextured). Statistical analysis by Tukey Multiple Comparison Test; ${ }^{*} p<0.05$, ${ }^{* *} p<0.01$, and ${ }^{* * *} p<0.001$. 


\section{Competing Interests}

The authors declare that they have no competing interests.

\section{Acknowledgments}

The authors would like to thank São Paulo Research Foundation (FAPESP) for financial support (Processes 2011/00702-0 and 2011/21982-0).

\section{References}

[1] S. T. Stern and S. E. McNeil, "Nanotechnology safety concerns revisited," Toxicological Sciences, vol. 101, no. 1, pp. 4-21, 2008.

[2] R. Bhola, F. Su, and C. E. Krull, "Functionalization of titanium based metallic biomaterials for implant applications," Journal of Materials Science: Materials in Medicine, vol. 22, no. 5, pp. 11471159, 2011.

[3] L. Tolstunov, "Implant zones of the jaws: implant location and related success rate," The Journal of Oral Implantology, vol. 33, no. 4, pp. 211-220, 2007.

[4] K. Nishio, M. Neo, H. Akiyama et al., "The effect of alkaliand heat-treated titanium and apatite-formed titanium on osteoblastic differentiation of bone marrow cells," Journal of Biomedical Materials Research, vol. 52, no. 4, pp. 652-661, 2000.

[5] F. Variola, A. Lauria, A. Nanci, and F. Rosei, "Influence of treatment conditions on the chemical oxidative activity of $\mathrm{H}_{2} \mathrm{SO}_{4} / \mathrm{H}_{2} \mathrm{O}_{2}$ mixtures for modulating the topography of titanium," Advanced Engineering Materials, vol. 11, no. 12, pp. B227B234, 2009.

[6] R. Kriparamanan, P. Aswath, A. Zhou, L. Tang, and K. T. Nguyen, "Nanotopography: cellular responses to nanostructured materials," Journal of Nanoscience and Nanotechnology, vol. 6, no. 7, pp. 1905-1919, 2006.

[7] J. S. Colombo, A. Carley, G. J. P. Fleming, S. J. Crean, A. J. Sloan, and R. J. Waddington, "Osteogenic potential of bone marrow stromal cells on smooth, roughened, and tricalcium phosphatemodified titanium alloy surfaces," The International Journal of Oral \& Maxillofacial Implants, vol. 27, no. 5, pp. 1029-1042, 2012.

[8] B.-A. Lee, C.-H. Kang, M.-S. Vang et al., "Surface characteristics and osteoblastic cell response of alkali-and heat-treated titanium-8tantalum-3niobium alloy," Journal of Periodontal and Implant Science, vol. 42, no. 6, pp. 248-255, 2012.

[9] X. Rausch-Fan, Z. Qu, M. Wieland, M. Matejka, and A. Schedle, "Differentiation and cytokine synthesis of human alveolar osteoblasts compared to osteoblast-like cells (MG63) in response to titanium surfaces," Dental Materials, vol. 24, no. 1, pp. 102-110, 2008.

[10] M. R. W. Ferreira, J. Dernowsek, G. A. Passos, and K. F. Bombonato-Prado, "Undifferentiated pulp cells and odontoblast-like cells share genes involved in the process of odontogenesis," Archives of Oral Biology, vol. 60, no. 4, pp. 593-599, 2015.

[11] K. F. Bombonato-Prado, L. S. Bellesini, C. M. Junta, M. M. Marques, G. A. Passos, and A. L. Rosa, "Microarray-based gene expression analysis of human osteoblasts in response to different biomaterials," Journal of Biomedical Materials Research Part A, vol. 88, no. 2, pp. 401-408, 2009.

[12] C. A. Gregory, W. G. Gunn, A. Peister, and D. J. Prockop, "An Alizarin red-based assay of mineralization by adherent cells in culture: comparison with cetylpyridinium chloride extraction," Analytical Biochemistry, vol. 329, no. 1, pp. 77-84, 2004.
[13] M. B. Eisen, P. T. Spellman, P. O. Brown, and D. Botstein, "Cluster analysis and display of genome-wide expression patterns," Proceedings of the National Academy of Sciences of the United States of America, vol. 95, no. 25, pp. 14863-14868, 1998.

[14] F. Vetrone, F. Variola, P. T. De Oliveira et al., "Nanoscale oxidative patterning of metallic surfaces to modulate cell activity and fate," Nano Letters, vol. 9, no. 2, pp. 659-665, 2009.

[15] F. Variola, J.-H. Yi, L. Richert, J. D. Wuest, F. Rosei, and A. Nanci, "Tailoring the surface properties of Ti6Al4V by controlled chemical oxidation," Biomaterials, vol. 29, no. 10, pp. 1285-1298, 2008.

[16] P. Santiago-Medina, P. A. Sundaram, and N. Diffoot-Carlo, "The effects of micro arc oxidation of gamma titanium aluminide surfaces on osteoblast adhesion and differentiation," Journal of Materials Science: Materials in Medicine, vol. 25, no. 6, pp. 15771587, 2014.

[17] S. Zanotti and E. Canalis, "Notch and the skeleton," Molecular and Cellular Biology, vol. 30, no. 4, pp. 886-896, 2010.

[18] N. Chakravorty, S. Hamlet, A. Jaiprakash et al., "Pro-osteogenic topographical cues promote early activation of osteoprogenitor differentiation via enhanced TGF $\beta$, Wnt, and Notch signaling," Clinical Oral Implants Research, vol. 25, no. 4, pp. 475-486, 2014.

[19] S. Roberts, S. Narisawa, D. Harmey, J. L. Millán, and C. Farquharson, "Functional involvement of PHOSPHO1 in matrix vesicle-mediated skeletal mineralization," Journal of Bone and Mineral Research, vol. 22, no. 4, pp. 617-627, 2007.

[20] A. Nakano, D. Koinuma, K. Miyazawa et al., "Pin1 downregulates transforming growth factor- $\beta$ (TGF- $\beta$ ) signaling by inducing degradation of Smad proteins," The Journal of Biological Chemistry, vol. 284, no. 10, pp. 6109-6115, 2009.

[21] M. J. Feito, R. M. Lozano, M. Alcaide et al., "Immobilization and bioactivity evaluation of FGF-1 and FGF-2 on powdered silicondoped hydroxyapatite and their scaffolds for bone tissue engineering," Journal of Materials Science: Materials in Medicine, vol. 22, no. 2, pp. 405-416, 2011.

[22] W. Wang, D. Olson, G. Liang et al., "Collagen XXIV (Col24 $\alpha 1)$ promotes osteoblastic differentiation and mineralization through TGF- $\beta$ /smads signaling pathway," International Journal of Biological Sciences, vol. 8, no. 10, pp. 1310-1322, 2012.

[23] N. Matsuo, S. Tanaka, H. Yoshioka, M. Koch, M. K. Gordon, and F. Ramirez, "Collagen XXIV (Col24al) gene expression is a specific marker of osteoblast differentiation and bone formation," Connective Tissue Research, vol. 49, no. 2, pp. 6875, 2008.

[24] L. Prodanov, C. M. Semeins, J. J. W. A. van Loon et al., "Influence of nanostructural environment and fluid flow on osteoblastlike cell behavior: a model for cell-mechanics studies," Acta Biomaterialia, vol. 9, no. 5, pp. 6653-6662, 2013.

[25] X. Zhao, D. Xu, Y. Li et al., "MicroRNAs regulate bone metabolism," Journal of Bone and Mineral Metabolism, vol. 32, no. 3, pp. 221-231, 2014.

[26] J. H. An, J. H. Ohn, J. A. Song et al., "Changes of microRNA profile and microRNA-mRNA regulatory network in bones of ovariectomized mice," Journal of Bone and Mineral Research, vol. 29, no. 3, pp. 644-656, 2014.

[27] D. M. Poitz, F. Stölzel, L. Arabanian et al., "MiR-134-mediated $\beta 1$ integrin expression and function in mesenchymal stem cells," Biochimica et Biophysica Acta (BBA)-Molecular Cell Research, vol. 1833, no. 12, pp. 3396-3404, 2013.

[28] Y.-F. Lan, H.-H. Chen, P.-F. Lai et al., "MicroRNA-494 reduces ATF3 expression and promotes AKI," Journal of the American Society of Nephrology, vol. 23, no. 12, pp. 2012-2023, 2012. 
[29] S. R. Baglio, V. Devescovi, D. Granchi, and N. Baldini, "MicroRNA expression profiling of human bone marrow mesenchymal stem cells during osteogenic differentiation reveals osterix regulation by miR-31," Gene, vol. 527, no. 1, pp. 321-331, 2013.

[30] Y. Gao, A. Jheon, H. Nourkeyhani, H. Kobayashi, and B. Ganss, "Molecular cloning, structure, expression, and chromosomal localization of the human osterix (SP7) gene," Gene, vol. 341, no. 1-2, pp. 101-110, 2004.

[31] Y. Deng, S. Wu, X. Bi et al., "Effects of a miR-31, Runx2, and Satb2 regulatory loop on the osteogenic differentiation of bone mesenchymal stem cells," Stem Cells and Development, vol. 22, no. 16, pp. 2278-2286, 2013.

[32] J. Gao, T. Yang, J. Han et al., "MicroRNA expression during osteogenic differentiation of human multipotent mesenchymal stromal cells from Bone Marrow," Journal of Cellular Biochemistry, vol. 112, no. 7, pp. 1844-1856, 2011.

[33] M. S. Rajeevan, S. D. Vernon, N. Taysavang, and E. R. Unger, "Validation of array-based gene expression profiles by real-time (kinetic) RT-PCR," Journal of Molecular Diagnostics, vol. 3, no. 1, pp. 26-31, 2001.

[34] P. B. Dallas, N. G. Gottardo, M. J. Firth et al., "Gene expression levels assessed by oligonucleotide microarray analysis and quantitative real-time RT-PCR-how well do they correlate?" BMC Genomics, vol. 6, article 59, 2005.

[35] K. Allanach, M. Mengel, G. Einecke et al., "Comparing microarray versus RT-PCR assessment of renal allograft biopsies: similar performance despite different dynamic ranges," American Journal of Transplantation, vol. 8, no. 5, pp. 1006-1015, 2008.

[36] W. Etienne, M. H. Meyer, J. Peppers, and R. A. Meyer Jr., "Comparison of mRNA gene expression by RT-PCR and DNA microarray," BioTechniques, vol. 36, no. 4, pp. 618-626, 2004.

[37] J. S. Morey, J. C. Ryan, and F. M. Van Dolah, "Microarray validation: factors influencing correlation between oligonucleotide microarrays and real-time PCR," Biological Procedures Online, vol. 8, no. 1, pp. 175-193, 2006. 

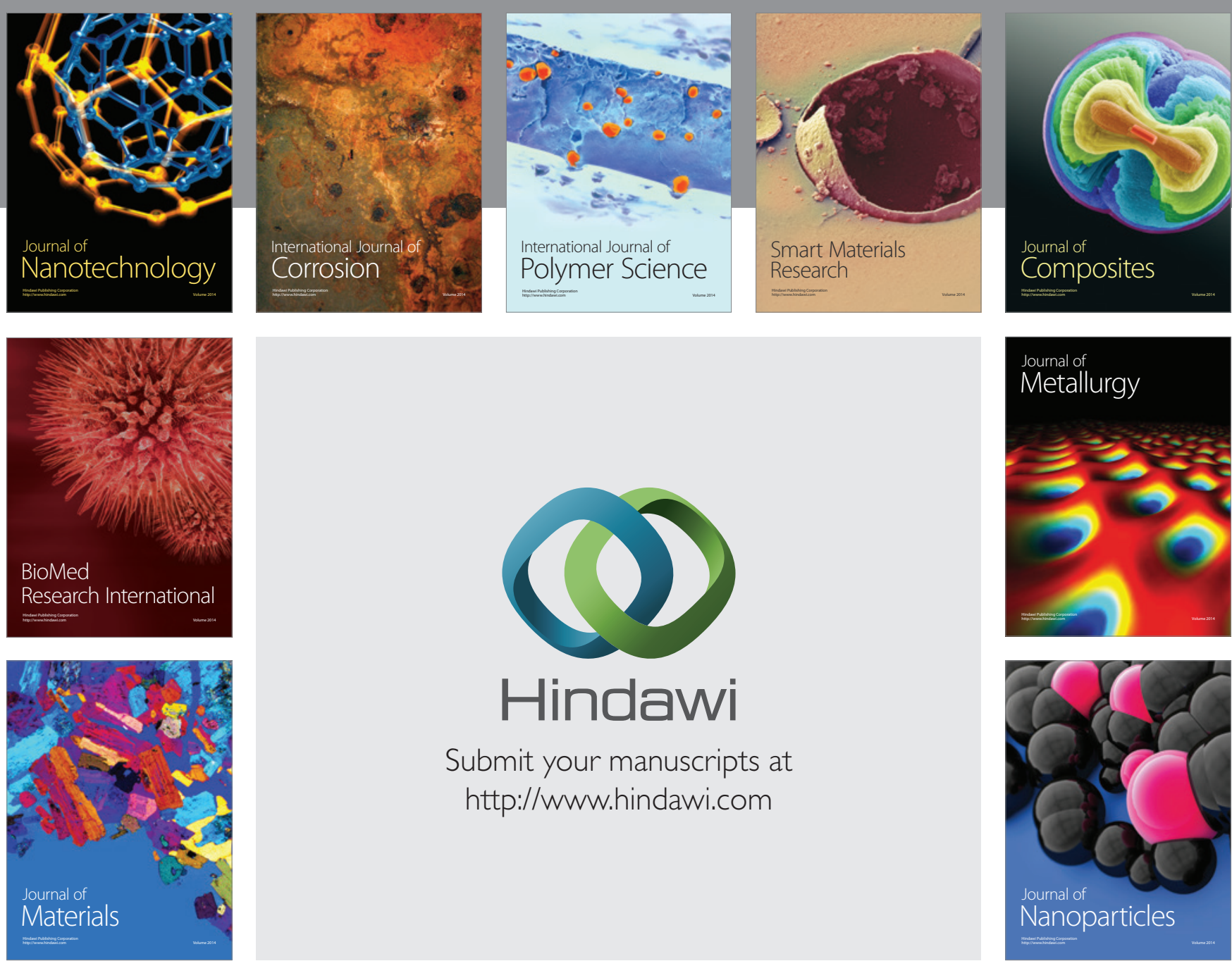

\section{Hindawi}

Submit your manuscripts at

http://www.hindawi.com

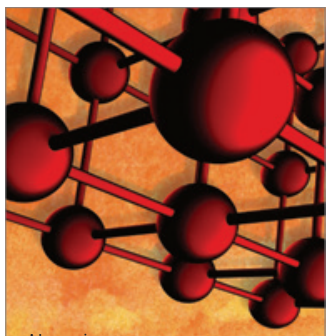

Materials Science and Engineering
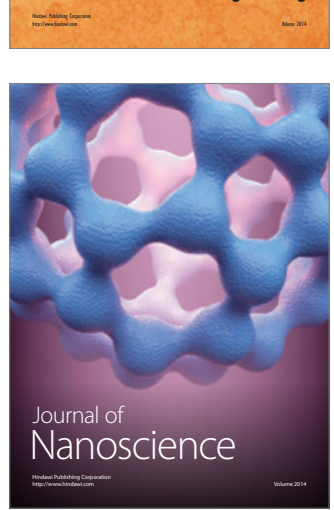
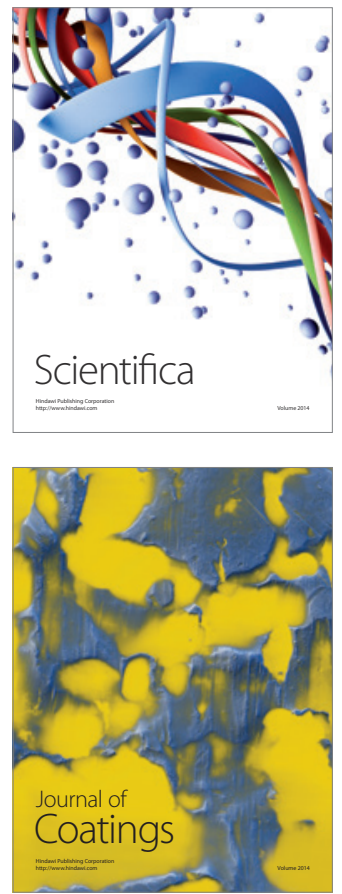
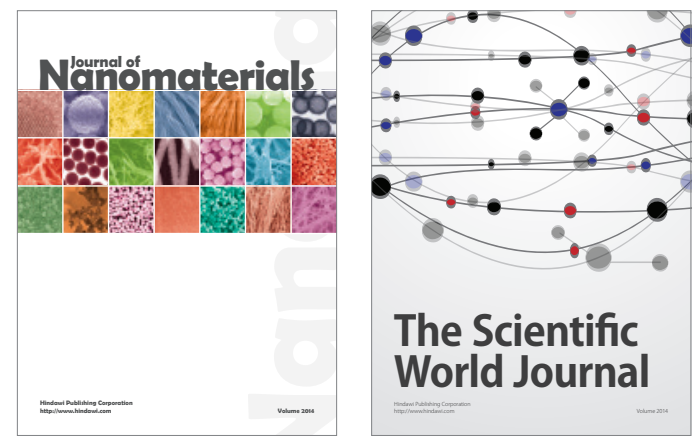

The Scientific World Journal
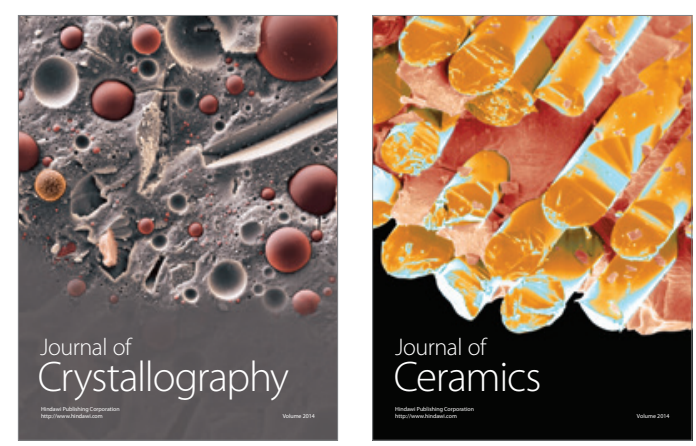
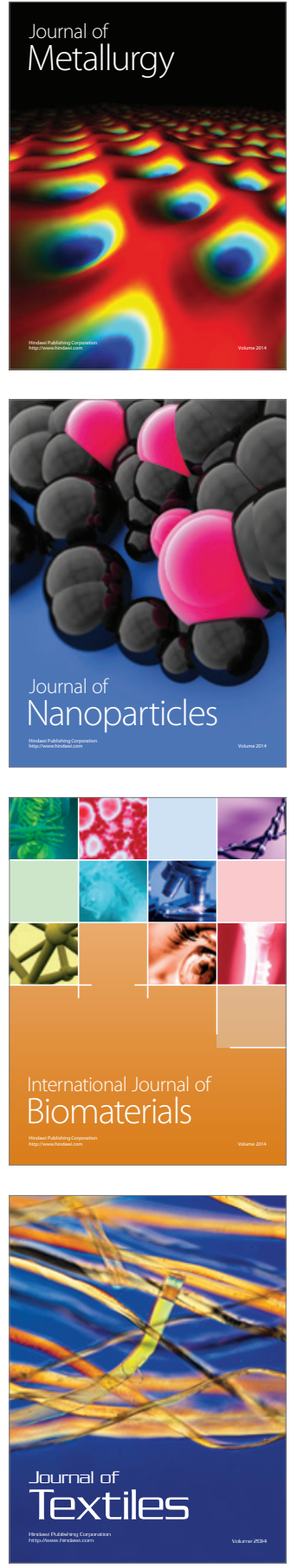